\title{
A múltak átalakulása \\ Jelentéstani és narratív lehorgonyzó módosulások a magyar múlt időkben a 18. század után*
}

1. Bevezetés. Arany János levelet írt Petőfinek 1847. április 21-én. Négy nappal korábban leégett Nagyszalonta. A valóban drámai eseményt Arany így írta le barátjának (Arany 1975: 86-87) ${ }^{1}$ :

(1) „Megkondúl a vészharang. Szét futunk. Egyetlen rosz fecskendőnket néhányan megragadjuk, - mert a lovakat várni késő volt; [...] A városház teljesen lángban van, körülvéve a leomlott égö náddal s nincs egy lélek körülte: de minek is - ? a védés lehetetlen. Rémülten futok lakomra, melly cserép födelü ugyan, de azért nem biztos: mert látok cserepes épületeket lángbaborulni. [...] A tüzveszély szélső vonala lakom megett húzódott át. Kerítésem, ólam, kertem teljes épségben maradt, s most - bár a város, mondani, egészen nyugotra fekütt lakom megett, az én kerítésem maradt legszélsővé - azontúl a gyepig rom, meg rom. [...] Azonban ez még nem volt elég. A lenyugvó nap vérveres szemet vete vissza a füstölgő romokra; az ellankadt emberek pihenni ültek le, nem azért, mintha már nem volna veszély, hanem mivel végképp kimerített erejök megtagadta a további szolgálatot. Egyszerre zúgva jő nyugotról a szél, szikrákat szórva a még folyvást égő romok közül, mind inkább gerjesztve ezeket, $\mathrm{s}$ a város hátramaradt keleti részét is végveszéllyel fenyegetve. Ez méginkább megölé reményemet; mert a déli tủz csak haránt szolgált lakomra: de ez egyenesen annak tartott. Én, s rólam az egész város .... már bizonyosnak hivém. Magam, nőm, egy két szomszédnő és gyerek .... ennyien valánk a gát, mellynek a vészrohamot meg kellett akasztania dühöngésében! Ugy-e regényes? A nők jajgattak s kezeiket törték; reményem nekem sem volt ugyan, de azért edényt ragadtam, s öntözni kezdém az égő romokat. Buzdításomra a nők is ezt tevék. [...] Zápor ömlött a romokra - hosszas - órákig tartó. Soha szebb zenét nem hallottam, mint e zápor suhogása. Nem olthatta ugyan ki a romokat, de megáztatá a fedeleket, s ellocsolá a repülő szikrát, és parázst. Ez éjt, s még egy másikat felöltözötten virrasztánk át; [...]."

Arany három nappal korábban két levelet írt, egyet Csengery Antalnak, egyet közhírré tételre, mindkettőt a városnak segítséget kérve (Arany 1975: 84-85). A két levél rövid, majdnem szükszavú, tárgyilagos:

* A Magyar Tudományos Akadémia székházában Budapesten, 2017. január 16-án elhangzott akadémiai rendes tagsági székfoglaló előadás szerkesztett változata. A tanulmány az OTKA K100717 Funkcionális kognitív nyelvészeti kutatás címü pályázati támogatása keretében készült.

${ }^{1}$ Itt és a továbbiakban a példamondatokban kiemelt igealakok kurziválása a szerkesztőségtől származik. A szórványos eredeti kiemelésekre a hivatkozások lapszáma után külön utalunk.

Magyar Nyelv 113. 2017: 10-26. DOI: 10.18349/MagyarNyelv.2017.1.10 
(2) ,a város egyik szélén tüz ütött ki, melly [...] [a városnak] többet négy ötöd részénél, tehát mintegy ezer házat, ide nem számlálva az udvarokon volt mindenféle gazdasági épületeket elhamvasztott. Leégett templomunk, tornyunk, harangjaink részint leolvadtak, részint lehullva széttöredeztek, leégett egyik lelkészi lakunk, tanítóink lakai közül többen, városházunk minden irományokkal együtt.”

Arany Petőfihez írt levele nem csupán saját életének, a szalontaiak sorsának egy megrázó pillanatát mutatja be, hanem a magyar nyelv történetének egy fontos szakaszát is leképezi metonimikusan. Talán nem szükítjük le az Arany-írásra tekintés nézőpontját bántóan, ha most azt emeljük ki, hogy a Petőfihez írt levél a tüzvészt alakilag három igeidőben beszéli el, méghozzá nagyjából ebben a sorrendben: alakilag jelen időben, jelentésében múltban (ez a praesens historicum), a - $t$ jelet alkalmazó múlt időben (ezt egyszerủ múlt időnek nevezem, ezt minden nap gyakoroljuk) és az -á/-é jeles múlt időben (ennek a neve elbeszélő múlt idő, ezt ismerjük például a Himnuszból: „Öseinket felhozád / Kárpát szent bércére” vagy a Szózatból: „Az nem lehet, hogy annyi szív / Hiába onta vért"). Vajon miért formálta meg történetelbeszélését Arany ekképp, mikor a segélykérő levelekben csak a -t jeles múltat használta? Aligha felételezhetjük Aranyról, hogy esetlegesen keverte az igeidőket.

2. A kérdés vázolása. Általánosabban tekintve az most a fó kérdés, hogy mire való volt a kétféle múlt, amelyek közül a legutóbbi összefoglaló magyar nyelvtörténet szerint az -á/-é jeles elbeszélő múlt már kiveszőben volt, használata a 19. század első felében bizonytalan és következetlen volt (SÁROSI 2003: 722). Vajon valóban nem volt már különbség a két múlt között ekkor? S ha mégis volt funkciója, midőn eltünt az -á/-é jeles múlt, akkor mi lett a helyén? Hiány? Más konstruálási módok léptek be? Hogyan alakultak át a múltak, miképp konstruálta meg a magyar anyanyelvű beszélő a múltat régen, majd később, a modernségben, és mi ennek a következménye? Ez előadásom témája.

Miért érdemes mindezzel foglalkozni, a szükebb nyelvtudományon túl is tekintve? Azért, mert az idő meghatározó tényezője minden kultúrának, s az időről való beszéd módjai pedig alakítják a múltról, jelenről és jövőről való tudást. $\mathrm{S}$ az időről való beszéd olyan, mint a más dolgokról való beszéd. Láttuk az idézett levélben, Arany háromféle időt alkalmaz egy esemény elbeszélésére. S a mai nyelvi tudásunkkal is észrevehetjük, hogy az első rész jelen ideje mintegy élő tudósításként érthető. A második rész egyszerü múlt ideje a bevégzett tényeket sorolja, Arany családjának és házának megmenekülésével - mint utóbb kiderül, időlegesen. A harmadik rész a levélírót legközvetlenebbül fenyegető veszélyt beszéli el elbeszélő múltban, tehát múltként, de teljes, azonnali átéléssel, áttétel nélküli tapasztalásként.

A következőkben a korábbi kutatások rövid összefoglalása után először az idő nyelvi leképezését, kifejezését mutatom be, majd ebben az általános keretben az igealakkal kifejezett két magyar múlt idő 19. századi jelentését részletezem. A létigével jelölt összetett múlt időkkel és a jelennel itt nem foglalkozom, azok szemantikai profilja eltér a két véges igealakú múltétól. Szintén nem térek ki a régebbi korok nyelvhasználatára, bár nyilvánvalóan összefüggésben állnak az elbeszélő múlt 19. századi sorsával. 
Végül arra térek ki, hogy milyen tapasztalati és kulturális motiváló erők segíthették az elbeszélő múlt eltủnését. Illetve szólni kell arról, ami maradt: az egyszerü múlt, a körülírás és a nyelvi hiány meglétéről, és hogy mindez hogyan változtatta meg a múltról való beszéd lehetőségeit. A múltról való beszéd módjai pedig hatnak a jelennel és a jövővel kapcsolatos megszólalásainkra.

A következők mellett kívánok érvelni az előadásban:

a) a nyelvtani idő összefügg az idő általános (nem csak nyelvi) feldolgozásával;

b) a két múlt idő szignifikáns mértékben különbözött a 19. században is, funkciójuk egymáshoz viszonyítva müködött;

c) az elbeszélő múlt a beszélőhöz képest episztemikus közvetlenséget, az átélést és a szemtanúságot fejezte ki, míg az egyszerú múlt a beszélőtől eltávolított múltat;

d) a múlt idők, mint az igeidők általában, csak az ige belső időbeliségével és a mondat időszerkezetével együtt értelmezhetők;

e) az elbeszélő múlt eltünése jelentős változást eredményezett a magyar nyelv szemantikai és szintaktikai rendszerében;

f) az elbeszélő múlt eltűnése összefügg az időfogalom és az elbeszélés változásával.

A bemutatás tudományos kerete a funkcionális kognitív nyelvészet, amelynek a következő alapelveit érvényesítem.

A nyelv mint tudás nem autonóm jelenség, szoros összefüggésben áll a világról való tudással: a világról való tudás a megismerési módok, az elmemüködés lehetőségei szerint rendeződik el fogalmi struktúrákban (LANGACKER 1987; GIVÓN 2001; TOMASELLO 2002; TOMASELLO 2003 ed.). A nyelvi tevékenység nem pusztán közvetítés vagy átadás, hanem interszubjektív: a beszélőtársak együtt hozzák létre a kommunikációs folyamatot és azon belül a megértést (LUHMANN 1998; TOMASELLO 2002; TÁTRAI 2011). A nyelv inherensen variábilis: sokfélesége megmutatkozik a kifejezés dinamikus alakíthatóságában éppúgy, mint a közösségileg rögzített belső változatokban (vö. LABOV 1982; vö. LANGACKER 1987 képiség-fogalmával). A jelen leírás nyelvtudományi kerete mindezért a használati alapú nyelvtudomány, amely a rendszer és a használat egységét állítja (LANGACKER 1987; TOMASELLO ed. 1998; KEMMER-BARLOW 2000), mert a beszélők számára természetes ez az egység.

A használati alapú funkcionális nyelvészet általános elméleti tételei a következők: 1. A nyelvi rendszer elemeit a mindenkori beszélő nézőpontjából kell bemutatni, hiszen a mindenkori beszélő aktuális perspektívája alakítja a közlés nyelvi szerkezetét. - 2. A nyelvi kifejezéseket jellegzetes, gyakori közegükben kell leírni, nem önmagukban. - 3. A jelentés egyenrangú az alakkal (az alaktani, mondattani szerkezetekkel), a jelentésszerkezetekből erednek a morfológiai és szintaktikai szerkezetek. A tényleges kifejtés alapjául az Osiris Kiadónál megjelenendő, MARKÓ ALEXANDRA, LADÁNYI MÁRIA, IMRÉNYI ANDRÁS, KUGLER NÓRA és TÁTRAI SzILÁRD szerzőtársaimmal készített Osiris Nyelvtan szolgál.

3. A kutatási előzmények. A 18. század végi, 19. század eleji magyar nyelvtanok mind létező igeidőként tartják számon az egyszerü (- $t$ jeles) mellett az elbeszélő múltat (valamint az összetett múlt időket) (vö. GYARMATHI 1794; Debre- 
ceni Grammatika 1795; KASSAI 1817; VERSEGHY 1821; Akadémia 1846). Ezek a nyelvtanok általában megegyeznek abban, hogy az egyszerü múltat összekapcsolják a befejezettség és a távolabbi múlt fogalmi tartalmával és funkciójával, míg az elbeszélő múlt szerepét inkább a befejezetlenség és a közeli múlt (,aligmúlt" vagy „félmúlt") kifejezésében jelölik meg. E funkciókijelölések általában a megnevezéssel (a felcímkézéssel) történnek meg, részletesebb elemzés nemigen olvasható. Két fontos megjegyzést azonban fel kell idézni. VERSEGHY nyelvtana röviden kifejti az „aligmúlt" jelentését: „A' Félig múlt (imperfectum) jelent olyan tselekedetet, melly, a mostani időhöz képest ugyan már el-múlt, de egy-más tselekedethez képest, a' melly épen a'kor foly vala, még nem múlt vala el, és így egy ollyan tselekedetet, a' melly sokáig tart, vagy gyakran elől adódik vala, p. o. Epen a'kor olvasok vala, midön a' Házamba bé-lépék' (VERSEGHY 1821: 151 - kiemelés az eredetiben). KASSAI JÓZSEF pedig az elbeszélő múlt szociolingvisztikai korlátozottságára mutat rá: „Ezen múltt üdő [az elbeszélő múlt] a' régieknél nagy divatbann vala; ma pedig tsak a' tudós Magyarok szólanak rajtta, a' köz nép többnyire a' múlttabbbal él, p. o. azt mondotta, hogy ott jártt, és semmire sem találtt. Hogy tehát a' köz-néptöl különbböztesse magát a' beszédbenn a' tudós: illik, hogy inkább [elbeszélö] múltt üdejű igékkel beszéljen és írjon" (KASSAI 1817: 188 - kiemelés az eredetiben).

A 19. század utolsó harmadában az elbeszélő múlt, általában a magyar múlt idők rendszere kiterjedt vita tárgyává vált. ARANY lentebb még idézendő kifejtése mellett többen állást foglaltak a magyar igeidőkről. A kérdésnek könyvet szentelt SZARVAS GÁBOR; eszerint a „történeti múlt” (vagyis az -á/-é jeles elbeszélö múlt) az elbeszélés fó eseményeit fejezi ki (SzARVAS 1872: 44, 302), míg az egyszerü (- $t$ jeles) múlt idő befejezett múltat jelöl (SZARVAS 1872: 267). A monográfia szerzője a magyar bibliafordításokra és más, a kódexirodalomból, illetve további, legkésőbb 16. századi nyelvemlékekre alapozza a korabeli jelenre is érvényesített állításait. KOVÁCS MENYHÉRT (valójában KICSKA EMIL) az ógörög és a szláv nyelvek általános időleképezésére alapozva, azoknak megfeleltetve bírálja SZARVAS munkáját. A leírásba bevonja a szótári ige temporális (lényegében aspektuális) jellemzőit, és azt hozza viszonyba az igeidővel, sokáig elfeledett módon. SIMONYI (1905: 412413) a - $t$ jeles múlt időt befejezettnek nevezi, a másikat elbeszélő időalaknak, etimológiájukra összpontosít, megelőlegezve E. ABAFFY $(1991,1992)$ álláspontját.

A magyar történeti múlt idők leírását az utóbbi időben főképp az igeidő és az aspektus összefüggéseivel kísérelték meg, gyakran autonóm jellegünek véve e kategóriákat, illetve az ige belső időbeliségét nem dolgozták ki a szükséges mértékben. Az értelmezések (vö. pl. J. SOLTÉSZ 1959; E. ABAFFY 1991, 1992; KIEFER 1996, 2006; NÉMETH 2001; É. KISS 2005; FAZAKAS 2007; HORVÁtH 2011; SZENTGYÖRGYI 2014; MOHAY 2015; HEGEDŰs 2016) egyrészt a múlt időknek a beszédidőhöz való lineáris viszonyát, valamint befejezettség szerinti aspektuális értékét veszik alapul, illetve azt hangsúlyozzák, hogy az igekötő történeti kialakulása és elterjedése eredményezte az igeidőrendszer leegyszerüsödését, főképp az elbeszélő múlt és az összetett múlt idők eltűnését. Ezek a nyelvtörténeti leírások föképp besorolás és ennek révén a funkciójelölés (funkciómegnevezés) révén jellemezték a múlt időket (az igeidőket), többnyire alaktani rendszerező nézőpontból kiindulva, főképp a régi történeti korokban, például a kódexek szövegeiben. 
Mindezt jól foglalja össze SÁROSI (2003: 153): a történeti magyarban az „elbeszélő múlt a jelennel kapcsolatban nem álló múlt kifejezése, múltbeli események elbeszélése”, míg a - $t$ jeles múlt idő „,a jelenre befejezett cselekvés jelölése, illetve később (a jelenben folyó vagy élőbeszédet tolmácsoló) párbeszédek múlt ideje". Kevés figyelmet kapott azonban NÉMETH RENÁTA egy fontos megjegyzése az elbeszélő múlt funkciójáról: „Úgy képzelhetjük el őt [Martonfalvay Imrét Emlékiratai írása közben], mint aki szilárdan eltökélte, hogy most már igazán határozottan lép fel gazdáival szemben. Ilyenkor - $t$ jeles múltat használ. Igyekszik szem előtt tartani célját, de az emlékek sodra minduntalan magával ragadja: ilyenkor átvált elbeszélő múltba" (NÉMETH 2001: 134).

Az eddigi kutatásokat tovább bővítve az időbeliség nyelvi kifejezésének leírására a komplex megközelítés a célravezető, amelynek meghatározó tényezője az ige belső időszerkezete, a mondat temporális referenciakerete és a szöveg időstruktúrája, a beszélő mindenkori fogalmi konstruáló nézőpontjából. Az idő kifejezésének meghatározó tényezője a temporalitás beszélő általi fogalmi megragadása és egy részének nyelvi leképezése, megkonstruálása.

4. Az idő és az idő leképezése az igével. Az igék időbeli folyamatokat fejeznek ki. Az ige időbeliségével kapcsolatban az iskolában az igeidőket tanítják: mi a jelen és a múlt idő jele, hogyan fejezzük ki a jövőt. Az igének azonban kétféle ideje van: az egyik a belső idő (az inherens temporalitás), a másik a mondatbeli igeidő. A belső idő minden szótári igére jellemző, hiszen minden ige folyamatot fejez ki, amely időben történik: megy, áll, van, esik. Az igék azonban nem magukban állnak a szövegben, hanem mondatszerkezetek középponti részét képezik, ahol a beszélő nézőpontjának, konstruálási módjának, beszédidejének megfelelően valamilyen igeidőbe kerülnek, melyet alakilag is kifejezünk. A megy, áll, van, esik ige folyamatot fejez ki, amely folyamat megtörténhet a jelenben, megtörténhetett a múltban, és bekövetkezhet a jövőben is. Bármilyen igeidőben áll is az adott ige, a belső (inherens) temporalitása, a folyamat időbelisége megmarad: ment, menni fog, áll, állt, esett, esik, esni fog. A kétféle idő egyszerre és egymásra hatva érvényesül a mondatban, a szövegben, úgy, hogy összekapcsolódik egy harmadik idővel, a beszéd megértésének az idejével. Tehát amikor a magyar múlt időkről beszélünk, akkor tudnunk kell, hogy egy időbeli folyamat múltbeli lefutásáról van szó.

Az inherens idő a folyamatot kifejező nyelvi szerkezetek jelentésében pillanatnyi állapotok (azaz most-pontok) sorozata. Például a megy ige járással végrehajtott helyváltoztató mozgást fejez ki, amelyet a mozgó élőlény saját akaratból és energiaforrásból hajt végre. A megy ige a meghatározott mozgást időben fejezi ki, a mozgást pillanatnyi állapotok sorozataként. A pillanatnyi állapot (most-pont) a megy ige által jelölt mozgás komplex eseményében egy pillanatnyi konfiguráció fogalmi szerkezete. Ezek a pillanatnyi konfigurációk váltanak át sorban egymásból a következőbe. Ennek a jelentésnek a megkonstruálása szekvenciális feldolgozással (szekvenciális letapogatással, szkenneléssel) történik meg (1. az 1. ábrát, vö. LANGACKER 1987, 2008a, 2008b). Az egymásra következő pillanatnyi állapotok időbeli feldolgozása a szekvenciális letapogatás. 


\section{1. ábra}

Az idő feldolgozása

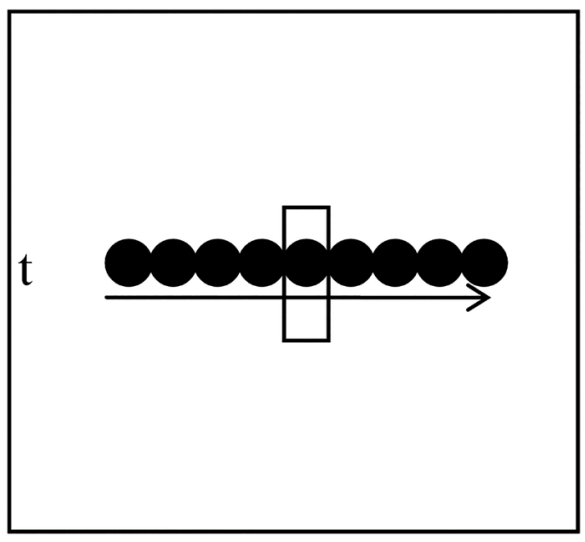

egy most-pont

Egy pillanatnyi állapot föltehetően megfelel az észlelés különböző, például vizuális és auditív müveleteit integráló perceptuális momentumnak, a másodperc törtrészének (vö. PÖPPEL 1994, 2009; 1. EVANS 2003: 26, 2013; TOLCSVAI NAGY 2015). Egy pillanatnyi állapot feltételezi az előtte és utána álló pillanatnyi állapotokat. A szekvenciális letapogatás, az egymásra következésen alapuló feldolgozás a filmkockák elemi állapotaiból összeálló folyamat feldolgozásával jellemezhető.

A folyamatot kifejező ige belső ideje ilyen pillanatnyi állapotok sorából áll. A folyamat idejét, a pillanatnyi állapotok sorát az adott nyelvi kifejezés, például az ige eseményszerkezete alakítja, az eseményszerkezet aktualizálja.

Az ige jelentésszerkezetének időbeli alszerkezete, a temporalitás szintén nagy változatosságot mutat. A következő tényezők különítendők el: tartam (hoszszúság és rövidség), kezdő- és végpont, intenzitás.

Minden mondatot, azaz minden szöveget valamilyen tér-idö kontinuumban mint referenciakeretben konstruál meg a beszélő (GIVÓN 1982; HEINE 1997; TRAugotT-DASHER 2002; Tolcsvai NAGY 2015; 1. még Chafe 1994). A referenciakeretet mint korlátozott kiterjedésü megismerési, vonatkozási, feldolgozási teret az észlelő és beszélő ember állítja föl: minden cselekedetünk, a puszta létezésünk térben és időben történik, és erről a temporalitásról mindig tudomásunk van. Az időre irányuló figyelem összetett, de korlátozott. Az emberi tudat folyamatosan feldolgozza és rendszeresen összegzi a környezetböl érkező hatásokat és a saját belső állapot alakulását. Mindez időben megy végbe.

A mondatokban az időbeli referenciakeret nézőpontszerkezetében a legfontosabb kiindulópont a beszélö (a konceptualizáló) perspektívája, azon belül a beszéd ideje. A beszélő számára saját beszédideje, annak a folyamata a kiindulópont, az időbeli referenciapont (amely a valóságban időbeli folyamat), mert az elbeszélt esemény ideje a beszéd feldolgozó idejéhez van viszonyítva az episztemikus lehorgonyzással. A beszélő számára a beszédidő mint referenciapont a mindenkori itt és a most.

Ebből a lehorgonyzó viszonyból ered a deiktikus igeidő, a magyarban a jelen, a múlt és a jövő: az elbeszélt esemény idejét a beszélő a beszéd itt és most idejéhez 
viszonyítja, ahhoz lehorgonyozza. A lexikális ige által kifejezett sematikus folyamat a megvalósulás során véges igealak lesz: a mondatban az ige által kifejezett folyamat lehorgonyzódik, a beszélő nézőpontjából, a beszédhelyzethez (az itt és mosthoz) viszonyítva (1. LANGACKER 1987, 1991; BRISARD 2002; BRISARD ed. 2002; PELYVÁs 1996, 1998, 2006; PATARD-BRISARD eds. 2011). Az időjellel minden esetben episztemikus lehorgonyzás történik, mert az igeidő (múlt, jelen, jövő) megértése csak a beszédhelyzetre való vonatkozással lehetséges. A jelen idő feldolgozása, megértése a beszédidővel való azonosítás révén lehetséges, a múlt feldolgozása, megértése a beszédidőt megelőző időtartammal vagy időponttal való azonosítás révén lehetséges. A lehorgonyzás folyamata a következő szakaszokból áll:

1. szótári ige belső temporalitással: esik;

2. véges igealak igeidővel (pl. alaki múltban): esett;

3. időbeli referenciakeret a beszélő nézőpontjával (a beszéd idejét megelözően történt): Tegnap esett az esö.

Eddig azt láttuk, hogy az ige egyrészt önmagában egy folyamat időbeliségét fejezi ki, másrészt az igeidővel mondatban véges igealakként lehorgonyzódik a beszédhelyzethez, a beszélő nézőpontjához. Látnunk kell azonban, hogy mindez viszonyba kerül a beszélő és a hallgató megértési müveleteivel, amelyek szintén időben történnek. Ez utóbbi a feldolgozó (megértő) idő. Vagyis az elbeszélt eseményt nem egy időponthoz viszonyítjuk, hanem a beszéd megértésének időbeli folyamatához, még ha az rövid is.

A feldolgozó idő általában nagyon rövid, a megértett idő jóval hosszabb is lehet. A megértett és feldolgozó idő közötti viszony fontos. A (3) mondat nagyon rövid eseményt fejez ki, a (4) mondat hosszút. A mondatok és bennük az igék megértése azonban nagyjából azonos rövid idő alatt történik meg (LANGACKER 2008a: 79 példája):

(3) Zsuzsa nagyot tüsszentett.

(4) A menet lassan vonult végig a városon.

5. Az egyszerü és az elbeszélő múlt jelentésszerkezete. A szótári és a véges, mondatbeli ige szemantikáját immár ismerve megvizsgálhatjuk az egyszerủ és az elbeszélő múlt jelentését. A korábbi szakirodalom az elbeszélő múltat hajlamos a folyamatosság kifejezésével jellemezni (a föntebb idézett nyelvtanok mellett 1. pl. KUGLER 2000: 114), míg az egyszerü múlt inkább a befejezettség funkciójával kapcsolódik össze, amíg az elbeszélő múlt még használatos.

Ám ha ez így lenne, nem lehetne érteni Arany levelének idézett részeit, illetve a teljes szöveget, pontosabban nem lehetne érteni Arany eljárását az igeidők váltogatásában. De mint láttuk, az igeidő nem magában áll: egyrészt viszonyban van az ige belső idejével, a kifejezett folyamat temporalitásával, másrészt a feldolgozó idővel, azzal, hogy a beszélő és a hallgató időben dolgozza fel a nyelvi közlést.

A prototipikus egyszerü és elbeszélő múltat az eddigiek ismeretében, nyelvi tapasztalataink alapján a következőképpen lehet bemutatni.

A) A prototipikus egyszerú múlt a 19. századi használatban, szembeállítva az elbeszélő múlttal, a következőképpen jellemezhető: 
1. egy múltbeli folyamat, amely pillanatnyi állapotok (konfigurációk) sorából áll, így dolgozza fel a beszélő és a hallgató;

2. van vagy lehet kezdő és végpontja, fóképp végpontja, inkább zárt;

3. az elbeszélt esemény bármilyen régiségü, hosszúságú és összetettségü lehet;

4. a folyamat múltbeli, tehát nem tapasztalható közvetlenül a beszélő által, nem a beszéd ideje alatt megy végbe, nincs megismerő közvetlenség, a konstruáló távolsága, vagyis a közvetett megismerés, a szemtanúság vagy az átélés hiánya a meghatározó;

5. nincs közvetlen megfelelés pillanatnyi állapotonként, vagyis most-pontonként az elbeszélt folyamat és a megértés (a beszéd) folyamata között, azok nem párhuzamosak, a feldolgozó folyamatot csak egészben, de időbeli folyamat jellegében dolgozza fel a megértő;

6. egyértelműen megmutatkozik az elbeszélt esemény múlt ideje és a beszéd jelen ideje közötti időbeli különbség, valamint a körülmények, korok közötti különbség.

E tulajdonságokból eredhet a „,befejezett” hatás. Példa az egyszerü múltra az Arany-levélből: „Kerítésem, ólam, kertem teljes épségben maradt”.

\section{2. ábra}

A múlt idő feldolgozása az egyszerü múltban

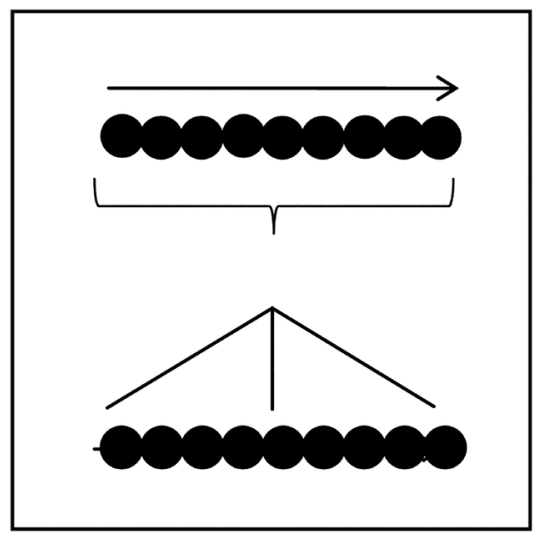

a jelen beszédidő (referenciapont, a beszéd feldolgozásának ideje, megértő idő)

B) A prototipikus elbeszélő múlt a 19. századi használatban, szembeállítva az egyszerü múlttal, a következőképpen jellemezhető:

1. egy múltbeli folyamat, amely pillanatnyi állapotok (konfigurációk) sorából áll, így dolgozza fel a beszélö és a hallgató;

2. van vagy lehet kezdő és végpontja, de nem ez áll a figyelem elöterében, inkább nyitott;

3. viszonylag rövid, a konceptualizáló szeme előtt lezajló időhorizont a jellemző (LUHMANN 1998: 1008);

4. az elbeszélt esemény múltbeli, a beszélő nézőpontja az esemény elbeszélésében mégis belülről érvényesül, a meghatározó a megismerő közvetlenség, vagyis 
a konstruáló közelsége, a közvetlen tapasztalása, a szemtanúság vagy az átélés megléte, mintha a beszélő közvetlenül tapasztalná a felidézett eseményt, annak idejét;

5. közvetlen megfelelés van pillanatnyi állapotonként, vagyis most-pontonként az elbeszélt esemény és a megértés folyamata között, azok párhuzamosak, a múltbeli folyamatot pillanatnyi állapotonként dolgozza fel a megértő, a saját feldolgozásának pillanatnyi állapotaival párhuzamosan;

6. a beszélői jelen és az elbeszélt múlt folyamata közötti távolság nincsen előtérbe helyezve időben, térben, körülményekben, kultúrában, mindez kívül esik a figyelmi hatókörön, éppen a közelség van jelölve, az, hogy a beszélő a múltbeli valóságban otthonos, a megkonstruált jelenet(sor), esemény számára ismert, köze van hozzá.

E tulajdonságokból eredhet a „folyamatos” hatás. Példa az elbeszélő múltra az Arany-levélből: „öntözni kezdém az égő romokat. Buzdításomra a nők is ezt tevék”.

\section{3. ábra}

A múlt idő feldolgozása az elbeszélő múltban

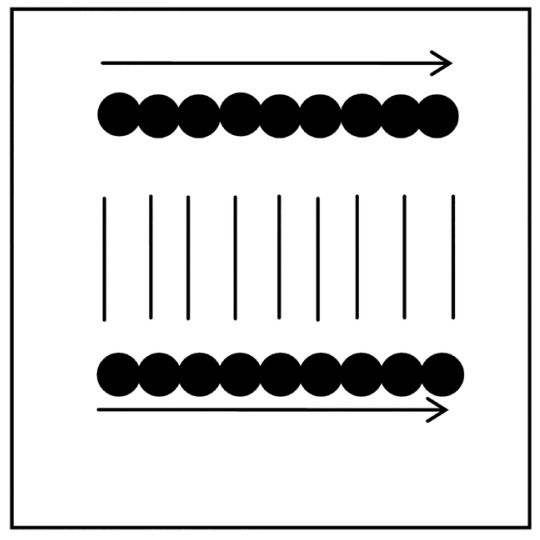

a jelen beszédidő (referenciapont, a beszéd feldolgozásának ideje, megértő idő)

a múltbeli elbeszélt esemény ideje (feldolgozott idö)

A múlt idő (ahogy minden igeidő) a mondatban a jelenet megkonstruálásában tényező (IMRÉNYI-KUGLER megj. a. rendszerében az első dimenzió, D1 a jelenet kifejezésében), a beszédaktus-érték szerint az időviszony kijelentése (D2), továbbá az időviszony kontextualizálása: távoli vagy közeli (D3).

A két múlt idő további vizsgálatakor, azok összehasonlítása során feltünik, hogy fontos tényező a beszélő (vagy konceptualizáló) implicit hiánya az egyszerü múltban és implicit jelenléte az elbeszélő múltban. E variabilitásnak egyik megnyilvánulása az evidencialitás: a megnyilatkozói tudásnak, az evidencia forrásának, típusának nyelvi jelölése (1. AIKHENVALD 2004; KUGLER 2015). Az egyszerü múltban ennek nincsen jele, az elbeszélő múltban közvetlen evidencialitás, szemtanúság esetén gyenge vagy közvetett változat érvényesül. A magyar múlt idők és az evidencialitás kapcsolatát veti fel POMOZI (2014).

Másik megnyilvánulása a szubjektivizáció: a beszélő vagy valamely más cselekvő nem kifejtett, azaz bennfoglalt jelenléte, attitüdjének vagy hiedelmeinek, 
nézőpontjának a rejtett kifejezése által, egy mondatban vagy szövegrészletben, anélkül, hogy a mondat vagy szövegrészlet nyílt és objektivizált résztvevőjévé válna (vö. TRAUGOTT 1989; LANGACKER 2006; KUGLER 2013).

Hozzá kell tenni, hogy e két igeidő funkcionálásában további tényezők is szerepet játszanak. Ilyen az igék idő- és eseményszerkezete általában, illetve ilyen a 19. században még gyakori szenvedő szerkezet, a létigés múltak és a határozói igeneves időszerkezetek sora.

Amikor most visszalapozunk Arany leveléhez, akkor láthatjuk, hogy a szövegben az egyszerü múlt elsősorban úgy mutatja be az eseményeket, állapotokat, mint amelyek esetében nem fontos a megismerő közvetlenség, a konstruáló távolsága, a közvetett megismerés, de meghatározó a szemtanúság vagy az átélés hiánya, nincs közvetlen megfelelés pillanatnyi állapotonként, vagyis most-pontonként az elbeszélt folyamat és a megértés folyamata között, a tüzvész időleges eredménye mintegy távoli az elbeszélő nézőpontjából.

Ezzel szemben az elbeszélő múlt a tüzvész újbóli feltámadását képezi le, amelynek során a beszélő (itt Arany) személyesen is érintett, és ezt a személyes érintettség perspektívájából mutatja be: a folyamat múltbeli, de mégis közvetlenül tapasztalható a beszélő által, a feldolgozó idő folyamata (a megértés idejében a most-pontok letapogatása) és az elbeszélt esemény részeként megértett idő (a leképezett folyamat most-pontjainak a letapogatása) profiláltan párhuzamos, közvetlen megfelelés van pillanatnyi állapotonként. Vagyis megfelelés van most-pontonként az elbeszélt folyamat és a megértés folyamata között, azok párhuzamosak, a múltbeli folyamatot pillanatnyi állapotonként dolgozza fel a megértö, a saját feldolgozásának pillanatnyi állapotaival párhuzamosan, a beszélői jelen és az elbeszélt múlt folyamata közötti közelség van jelölve időben, térben, az, hogy a beszélő átéli a múltbeli eseményt.

Talán nem véletlen, hogy ARANY Visszatekintés címü tanulmányának a végén részletesen taglalja a két múlt idő funkcióit, s megállapítja, hogy az elbeszélő múlt a népnyelvben általában közvetlen múltat fejez ki. Ezt a kijelentést azonban rögtön árnyalja: „Van azonban eset, amikor ez aligmúlt jelentés nem vétetik oly szigorúan, hanem helyette a váratlanság, e miatti csodálkozás, sajnálat, szóval a felindulás valamely neme uralkodik s a pusztán idői vagy szókötési viszony jelölése helyett, a pusztán grammaticai árnyalat helyett oly magasabb szempont áll be, mely már az érzelmi világba szolgál: ilyenkor régebben történt eseményre is vitetik az ék-ém forma. Például. Két ismerős hosszabb távollét után összetalálkozik; beszélgetnek az azóta történt változásokról s az egyik felsóhajt: »Meghala szegény Péter is!« Lehet, hogy Péter halála épen nem új dolog, de nekik nem volt még alkalmuk egymás közt emlegetni s mint váratlanul, csak most történtet hozzák fel. De a másik már így felelne rá: »Meg biz az, tavaly halt meg (nem hala) szegény! «" (ARANY 1938: 363 - az idézetbeli kiemelések itt Aranytól származnak).

6. Néhány példa. Eddig tartott az általánosítás, az idealizáló leírás. Ám ismeretes, hogy a sémaként számon tartott nyelvi konstrukciók számos változatban valósulnak meg a nyelvi tevékenységben. S valóban, az elbeszélő múlt használata mutat változatosságot, sőt következetlenséget és bizonytalanságot is a 19. század során. Néhány példát hozok föl, röviden, írott, de nem szépirodalmi munkákból. 
Kazinczy Ferenc Pályám emlékezete (1827-1828) című mủvében igen sürün élt az elbeszélő múlttal, meglehetős, bár nem teljes következetességgel, de a fö irányt tartotta. Nála inkább azt lehet tapasztalni, hogy az egyszerü múlt is előfordul olyan helyeken, ahol az elbeszélő jöhetne. A múlt idő közötti szerepkülönbség a nézőpontirányítás egyik fontos eljárása itt. Az egyszerü múlt azt jelöli, ami szokás, általános, hosszabb távú vagy hosszabb érvényü vagy lezárult a múltban. Az elbeszélő múlt ezzel szemben azt fejezi ki, ami közvetlen élmény, valós vagy elképzelt. Két jellemző részlet a müből ezt mutatja be: „Bossányi Ferencnek ifjabb, sőt még férfiéveiben is, igen szép keze-írása volt, 's sorai egyenest folytak mind oldalt, mind legelé, mintha lineázva volna a' papiros: most reszkete jobbja, 's nagy fáradsággal, de még mindég egyenest és igen csinosan irt; 's ez miatt hol patvaristát tarta, még hivatalt nem viselvén is, hol írni-tudó inast” (Kazinczy 2009: 473). - „Egy nap (1774.) tavasz' elején atyám 's anyám látni jövének. Minthogy Regmecz Patakhoz csak három órányi távolban van, még az nap haza tértek. Szokatlan aggodalom rohana rám elválásokkor. Felszökém szekerekre, 's messze kísértem el Újhely felé. Harmad nap múlva üresen jöve szekerek azon izenettel, hogy a' Katonai-Orvost küldjem ki, mert atyám rosszúl van, 's a'Vármegye' Orvosa falura vitetett. Mentem én is, 's ott maradék. - Mártzius' 20-dikán elhala, élte' 42-dik esztendejében; 's 38 esztendős Özvegyét hét élő gyermekkel hagyá, a' nyolczadik öt holnap múlva leve meg" (Kazinczy 2009: 478).

Kölcsey Ferenc egyes írásaiban és beszédeiben nincsen elbeszélő múlt. Ilyen például A szatmári adózó nép állapotáról mondott nevezetes beszéde, illetve a sok vitát gerjesztő bírálata: Csokonai Vitéz Mihály munkáinak kritikai megítéltetések. Ugyanakkor más szövegeiben az elbeszélö múlt a közvetlen személyest mutatja, ami személyében is érinti, valamint ami folyamatként tapasztalható, míg az egyszerü múlt a közvetett és lezárt múltat fejezi ki. Búcsú az országos rendektől címü beszéde (1835) ezt példázza: „Szatmár megyének két követei, kik honunkból együtt jövének az ország törvényhozásában résztvenni, most utólszor állunk itt a T. KK. és RR. szép koszorújában [...] Mit valánk teendők? Engedni? Az szívünk győződésével meg nem fért. Nem engedni? Azt követi kötelességünk nem hagyta. Tehát folyamodánk küldőinkhez: szabadítanák fel régi elveinket: szabadítanák fel megkezdett pályánkat, melyen mi a haza szerencséjének eszközeit feltalálhatni reméltük. Nem tevék; s szabadságokban volt nem tenni” (Kölcsey 1975: 651-652).

Kemény Zsigmond esszéiben már kevés az elbeszélő múlt, s prototipikus funkciója alig müködik. Szövegeiben inkább a folyamatos jelleg uralkodik, az is elsősorban a vala igealakkal, amely múltbeli hosszabb időtartamot jelöl, illetve a határozói igenév és a szenvedő igealakokkal. Visszatekintések Erdély múltjára és gr. Bethlen János politikai pályájára című tanulmányában (1851) így ír: „Aztán már a Zápolyák korának végéveiben a latin nem vala Erdély kormánytanácsának és törvényhozó termének nyelve. A közigazgatás és közkezelés többnyire magyarul folyt. A nemzeti szellem s hang lön általános jelleme a múveltebb társadalmi életnek és a fejedelmek udvarában kizárólag uralkodott" (Kemény 1971: 46 - a Zápolyák szó kiemelése Keménytől származik). Illetve: „nem csoda, ha midőn Pozsonyban latin törvény, Bécsben német központosítási irány uralkodott, a részvét szünetlen új táplálékot nyert Erdély iránt, hol a nemzetiség utolsó védbástyái lerontva vagy elgyengítve még nem valának" (Kemény 1971: 47). 
Horváth Mihály Huszonöt év Magyarország történetéből (1868) című történeti munkája vegyes képet mutat. Az Előszóban nincs elbeszélő múlt, a részletező fejezetekben azonban előkerül, főképp a folyamat- vagy állapotjelleg temporalitását hangsúlyozandó.

7. Az időfogalom módosulása a 18. század végétől. Nincsen értelmes különbség a világról és a nyelvről való ismeretek között, a nyelv enciklopédikus jellegü. Ezért az idő tapasztalata leképeződik a nyelv időkonstrukcióiban, és az időtapasztalat változása megjelenik a nyelv időleképezésében (a nyelvi változásra 1. KELLER 1990; CROFT 2000; TRAUGOTT-DASHER 2002).

Az elbeszélő múlt kihalásának több oka kimutatható. E tényezők nem közvetlen okok, inkább motiváló kulturális hatások, amelyek a megismerés módjait és az abból eredő ismeretek jellegét alakították, elsősorban a korábban nem tapasztalt éles váltásokkal, vagyis az idő fogalmával kapcsolatos tapasztalati tér és az elváráshorizont átalakulásával. Ez volt az újkor megvalósulása, KOSELLECK (2003) értelmében.

Az igekötős szerkezetek kiterjedése a 18-19. században már nyilvánvaló tényező volt, ez már korábban is hatott, és amúgy ezt is kiváltotta valami.

A magyar sztenderd nyelvváltozat ugyan kodifikálta az elbeszélő múltat, de nem eröltette használatát, amely az írott szövegekkel szemben az élőbeszédben már nem volt gyakori. A „nyelvújítás” a növekvő mértékü közösségi reflexió az anyanyelvre. Ennek fó részeként a sztenderd kiválasztása és kodifikációja nem csupán közvetlenül a múlt idők rendszerére hathatott, hanem azzal a ténnyel, hogy maga a sztenderd korábban nem volt. Ezért a nyelvi múlt élesebben elválik a jelentöl. Ehhez járul a sztenderd kiterjesztése: ennek értelmében a jövő a sztenderd, az eszményi magyar nyelvé, amely időtlen egyetemes és kortárs európai kritériumoknak felel meg.

A reformkor, de különösen az 1848-49. évi forradalom és szabadságharc az egész társadalomra mint cselekvőre és mint elszenvedőre hatott. Az idő tapasztalata megváltozott: a közvetlen múlt is levált a jelenről, miközben az e világi jövővárás meghatározó lett. A nagyon gyors és alapvető társadalmi és politikai változások lerombolták az idő korábbi értelmezését, amely összefüggött a hagyomány értelmezésével, mely szerint az ősi az örök és állandó. A magyar romantikát nem jellemezte vallási megújulás, ugyanakkor a közösség, a nemzet eredetét és korábbi szakaszait elkülöníti a jelentől, amelyet a várt jövő felől értelmez (a Himnusz és a Szózat szövegében is).

A polgárosodás, iparosodás nyomán a természeti alapú feladatorientált időfelfogást fokozatosan felváltotta az óraorientált időfelfogás (DOBSZAY-FÓNAGY 2003: 70-72).

A felvilágosodásban a múlt általában jobban elvált a jelentől, körülhatároltabb és távolibb lett. Tényező lett az események egyszerisége, a hatástörténet jelentösége, a jövőnek, a jövőbeli újnak az elvárása és hatása a jelenre a fejlődés, haladás fogalmainak megjelenésével, a közösségi szemantika korábban nem látott módon dinamikusan alakult, amely összefüggött az információ új és közvetett jellegének fontossá válásával és a szemtanúságnak a háttérbe szorulásával. Mindeközben az eszkatológia jelentősége elhalványult (vö. LUHMANN 1998: 997-1016; KOSELLECK 2003: 17-40, 345-399). 
Ezek a kulturális folyamatok a múltat távolságként leképező nyelvi szerkezetnek kedveztek, egymást kölcsönösen erősítve.

8. Mi maradt? Az elbeszélő múlt múlttá válása után maradt:

1. az egyszerü múlt, kiterjesztve minden olyan múltként konstruált eseményre, amely egyszerű igealakkal kifejezhető, már nem az elbeszélő múlttal szemben és párban;

2. a hiány, mert az egyszerủ múlt ugyanakkor nem vette át az elbeszélő múlt funkcióit, nem fejez ki episztemikus közvetlenséget;

3. az imperfektív igealak (jellegzetesen igekötő nélkül), amely múlt időben képes egyfajta folyamatosságot kifejezni, de az episztemikus közvetlenséget kevéssé;

4. a körülírás, föképp az evidencialitás formáival, például: láttam, amikor..., hallottam, ahogy..., ott álltam, amikor ..., tapintani lehetett a..., Xmesélte, hogy...

Átalakult a magyar időkonstruálás, módosult magyar mondattan, és szükültek a történet elbeszélhetőségének a lehetőségei: közvetlenül nem tudjuk a múltbeli közvetlenséget kifejezni.

9. Összegzés. A fenti kifejtésben (mely számos további részlet kidolgozását kívánja meg) azt láttuk, hogy

1. a nyelvtani idő összefügg az idő általános (nem csak nyelvi) feldolgozásával;

2. az egyszerü és az elbeszélő múlt idő szignifikáns mértékben különbözött a 19. században is, az írott, magas színvonalú szövegekben;

3. az elbeszélő múlt a beszélőhöz képest episztemikus közvetlenséget, az átélést és a szemtanúságot fejezte ki, míg az egyszerü múlt a beszélőtől eltávolított múltat;

4. a múlt idők, mint az igeidők általában, csak az ige belső időbeliségével és a mondat időszerkezetével együtt értelmezhetők, és ennek megfelelően változnak.

Az elbeszélő múlt kihalása átalakította a magyar mondattan egy jelentős tartományát: a múltról való beszéd elsősorban objektivizációs, távolságtartó, megismerő közvetlenség nélküli módon lehetséges. A látszólag grammatikai, „ragozási” kérdés tehát a magyar közösségi szemantika alakulástörténetének egy jelentős szakaszára mutat rá, amely ma is jelentékenyen befolyásolja a múltról való beszéd lehetőségeit.

Kulcsszók: episztemikus lehorgonyzás, episztemikus közvetlenség, egyszerü múlt, elbeszélö múlt, múlt, szemtanúság, temporalitás.

\section{Hivatkozott irodalom}

E. ABAFFY ERZSÉBET 1991. Az igemód- és igeidőrendszer. In: BENKŐ LORÁND föszerk., A magyar nyelv történeti nyelvtana I. A korai ómagyar kor és elözményei. Akadémiai Kiadó, Budapest. 104-121.

E. ABAFFY ERZSÉBET 1992. Az igemód- és igeidőrendszer. In: BENKÖ LORÁND föszerk., A magyar nyelv történeti nyelvtana II/1. A kései ómagyar kor. Morfematika. Akadémiai Kiadó, Budapest. 120-183.

Aikhenvald, AleXandRa Y. 2004. Evidentiality. Oxford University Press, Oxford. 
Akadémia 1846 = A'magyar nyelv' rendszere. Közre bocsátá a’ Magyar Tudós Társaság, Budán.

ARANY JÁNOS 1938. Visszatekintés. In: Arany János összes prózai müvei és müforditásai. Franklin Társulat, Budapest. 309-366.

Arany János 1975. Arany János levelezése 1828-1851. Akadémiai Kiadó, Budapest.

BRISARD, FRANK 2002. Introduction: The epistemic basis of deixis and reference. In: BRISARD ed. 2002: xi-Xxxiv.

BRISARD, FrANK ed. 2002. Grounding. The Epistemic Footing of Deixis and Reference. Mouton de Gruyter, Berlin - New York.

Chafe, Wallace 1994. Discourse, Consciousness, and Time: The Flow and Displacement of Conscious Experience in Speaking and Writing. The University of Chicago Press, Chicago-London.

Croft, William 2000. Explaining Language Change. An Evolutionary Approach Longman, London.

Debreceni Grammatika 1795. Magyar Grammatika, mellyet készitett Debreczenben egy Magyar Társaság. A Magyar Hírmondó íróinak költségével, Alberti betüivel, Bétsbenn.

DOBSZAY TAMÁS - FÓNAGY ZOLTÁN 2003. A rendi társadalom utolsó évtizedei. In: GERGELY ANDRÁS szerk., Magyarország története a 19. században. Osiris Kiadó, Budapest. $57-123$.

EVANS, VyVyan 2003. The Structure of Time. Language, meaning and temporal cognition. John Benjamins, Amsterdam-Philadelphia.

Evans, Vyvyan 2013. Language and Time. A Cognitive Linguistics Approach. Cambridge University Press, Cambridge. http://doi.org/10.1017/CBO9781107340626

FAZAKAS EMESE 2007. A fel, le és alá magyar igekötők használata a kései ómagyar kortól napjainkig. Erdélyi Múzeum-Egyesület, Kolozsvár.

GIVÓN, TALMY 1982. Evidentiality and epistemic space. Studies in Language 6: 23-49.

GIVÓn, TALmy 2001. Syntax. An introduction. Revised edition. John Benjamins, Amsterdam-Philadelphia.

GYARMATHI SÁMUEL 1794. Okoskodva tanitó nyelvmester. Nyomtattatott Hochmeister Márton, Tsász K. Dicast. Könyvnyomtato és priv. Könyvárus betüivel, Kolozsváratt.

HeGEDÜS ATTILA 2016. Az összetett múlt idők és használatuk a kései ómagyar korban. Magyar Nyelv 112: 74-80. http://doi.org/10.18349/MagyarNyelv.2016.1.74

HEINE, BERND 1997. Cognitive Foundations of Grammar. Oxford University Press, Oxford. HORVÁTH LAURA 2011. Aspektusjelölés kései ómagyar és középmagyar kori szövegekben. In: É. KISS KATALIN - HEGEDÜS ATTILA szerk., Nyelvelmélet és diakrónia. PPKE BTK Elméleti Nyelvészeti Tanszék - Magyar Nyelvészeti Tanszék, Piliscsaba. 205-223.

Horváth Mihály 1868. Huszonöt év Magyarország történetéből. Ráth Mór, Pest. 2. kiadás. IMRÉNYI ANDRÁS - KUGLER NÓRA megj. a. Mondattan. In: TOLCSVAI NAGY GÁBOR szerk., Osiris Nyelvtan. Osiris Kiadó, Budapest.

KASSAI JÓzSEF 1817. Magyar Nyelvtanító Könyv. Sárospatakonn. Nyomtatá Nádaskay András.

Kazinczy Ferenc 2009. Pályám Emlékezete. In: Kazinczy Ferenc, Pályám Emlékezete. Debreceni Egyetemi Kiadó, Debrecen. 471-530.

KELLER, RUDI 1990. Sprachwandel. Von der unsichtbaren Hand in der Sprache. Francke Verlag, Tübingen. 
Kemény Zsigmond 1971. Visszatekintések Erdély múltjára és gr. Bethlen János politikai pályájára. In: Kemény Zsigmond, Élet és irodalom. Szépirodalmi Könyvkiadó, Budapest. 41-121.

KEMMER, SuZANNE - BARlow, Michael 2000. Introduction: A usage-based conception of language. In: BARLOw, MiCHAEL - KEMMER, SuZANNE eds., Usage-Based Models of Language. CSLI Publications, Stanford. vii-xxviii.

KIEFER FERENC 1996. Az igeaspektus areális-tipológiai szempontból. Magyar Nyelv 92: $257-262$.

KIEFER FERENC 2006. Aspektus és akcióminőség különös tekintettel a magyar nyelvre. Akadémiai Kiadó, Budapest.

É. KISS KATALIN 2005. Az ómagyar igeidőrendszer morfoszintaxisáról. Magyar Nyelv 101: 420-435.

Koselleck, ReInHART 2003. Elmúlt jövő. A történeti idők szemantikája. Atlantisz, Budapest.

Kölcsey Ferenc 1975. Válogatott müvei. Szépirodalmi Könyvkiadó, Budapest.

KovÁCs MENYHÉRT [KICSKA EMIL] 1881. A magyar igeidőkhöz. Magyar Nyelvőr 293303, 389-399.

KUGLER NÓRA 2000. Az igeragozás. In: KESZLER BorBÁLA szerk., Magyar grammatika. Nemzeti Tankönyvkiadó, Budapest. 104-126.

KUGLER NÓRA 2013. A szubjektivizáció jelenségének nyelvészeti értelmezései. Magyar Nyelvör 137: 8-30.

KUGLER NÓRA 2015. Megfigyelés és következtetés a nyelvi tevékenységben. Tinta Könyvkiadó, Budapest.

LABOV, WILLIAM 1982. Building on Empirical Foundations. In: LEHMANN, WILLIAM P. Malkiel, Yakov eds., Perspectives on Historical Linguistics. John Benjamins, Amsterdam-Philadelphia. 17-92.

LANGACKER, Ronald W. 1987. Foundations of Cognitive Grammar. Volume I. Theoretical Prerequisites. Stanford University Press, Stanford.

LANGACKER, RONALD W. 1991. Foundations of Cognitive Grammar. Volume II. Descriptive Application. Stanford University Press, Stanford.

LANGACKER, RONALD W. 2002. Deixis and subjectivity. In: BRISARD ed. 2002: 1-28.

LANGACKER, RONALD W. 2006. Subjectification, grammaticalization, and conceptual archetypes. In: ATHANASIADOU, ANGELIKI - CANAKIs, Costas - CoRnillie, BerT eds., Subjectification. Various paths to subjectivity. Mouton de Gruyter, Berlin New York. 17-40. http://doi.org/10.1515/9783110892970.17

Langacker, Ronald W. 2008a. Cognitive Grammar. A Basic Introduction. Oxford University Press, Oxford.

LANGACKER, Ronald W. 2008b. Sequential and summary scanning: A reply. Cognitive Linguistics 19: 571-584. http://doi.org/10.1515/COGL.2008.022

LuHMANN, NiKLAS 1998. Die Gesellschaft der Gesellschaft. Suhrkamp, Frankfurt am Main. MOHAY ZSUZSANNA 2015. Boszorkányperek múlt időben. In: ForGÁCS TAMÁS - NÉMETH MIKLÓS - SINKOVICS BALÁZS szerk., A magyar nyelvtörténeti kutatások újabb eredményei VIII. Szegedi Tudományegyetem Magyar Nyelvészeti Tanszék, Szeged. $121-128$. 
NÉMETH RENÁTA 2001. Múlt idejü igerendszerünk a korai középmagyar korban. In: BÜKY LÁSZLÓ - FORGÁCS TAMÁS szerk., A nyelvtörténeti kutatások újabb eredményei II. Magyar és finnugor alaktan. Szegedi Tudományegyetem Magyar Nyelvészeti Tanszék, Szeged. 131-138.

PATARD, ADELINE - BRISARD, FRANK eds. 2011. Cognitive approaches to tense, aspect and epistemic modality. John Benjamins, Amsterdam-Philadelphia. http://doi.org/[-] 10.1075/hcp. 29

PELYvÁs, PÉTER 1996. Subjectivity in English. Generative Grammar Versus the Cognitive Theory of Epistemic Grounding. Peter Lang, Frankfurt am Main.

PELYVÁs PÉTER 1998. A magyar segédigék és kognitív predikátumok episztemikus lehorgonyzó szerepéről. In: BÜKY LÁSZLÓ - MALECZKI MÁRTA szerk., A mai magyar nyelv leírásának újabb módszerei III. JATE, Szeged. 117-132.

PELYVÁS, PÉTER 2006. Subjectification in (expressions of) epistemic modality and the development of the grounding predication. In: ATHANASIADOU, ANGELIKI - CANAKIS, COSTAS - CORNILLIE, BERT eds., Subjectification. Various paths to subjectivity. Mouton de Gruyter, Berlin - New York. 121-150. http://doi.org/10.1515/9783110892970.121

POMOZI PÉTER 2014. A magyar múltidő-rendszer térben és időben az evidencialitás tükrében. In: FAZAKAS EMESE - JUHÁSZ DEZSŐ - T. SZABÓ CSILLA - TERBE ERIKA ZSEMLYEI BORBÁLA szerk., Tér, idő, társadalom és kultúra metszéspontjai a magyar nyelvben. ELTE Magyar Nyelvtörténeti, Szociolingvisztikai, Dialektológiai TanszékNemzetközi Magyarságtudományi Társaság, Budapest-Kolozsvár. 85-100.

PÖPPEL, ERNST 1994. Temporal mechanisms in perception. In: SPORNS, OLAF - TONONI, GIULIO eds., Selectionism and the brain. International review of neurobiology 37 . Academic Press, San Diego. 185-201. http://doi.org/10.1016/S0074-7742(08)60246-9

PÖPPEL, ERNST 2009. Pre-semantically defined temporal windows for cognitive processing. Philosophical Transactions of the Royal Society B 364: 1887-1896. http://doi.[-] org/10.1098/rstb.2009.0015

SÁROSI ZSÓFIA 2003. Morfématörténet. In: KISS JENŐ - PUSZTAI FERENC szerk., Magyar nyelvtörténet. Osiris, Budapest. 129-172, 352-371, 610-617, 719-724.

SimONYI Zsigmond 1905. A magyar nyelv. Athenaeum, Budapest. 2. kiadás.

J. SoltéSz KATAlin 1959. Az ősi magyar igekötők (meg, el, ki, be, fel, le). Akadémiai Kiadó, Budapest.

SZARVAS GÁBOR 1872. A magyar igeidők. Eggenberger, Pest.

SZENTGYÖRGYI RUDOLF 2014. Az ómagyar múlt idők rendszerének kiépülése. In: HAVAS FERENC - HORVÁTH KATALIN - KUGLER NÓRA - VLADÁR ZSUZSA szerk., Nyelvben a világ. Tanulmányok Ladányi Mária tiszteletére. Tinta Könyvkiadó, Budapest. $258-267$.

TÁTRAI SZILÁRD 2011. Bevezetés a pragmatikába. Funkcionális kognitív megközelités. Tinta Kiadó, Budapest.

Tolcsvai NAGy GÁBOR 2015. Az ige a magyar nyelvben. Funkcionális elemzés. Tinta Könyvkiadó, Budapest.

Tomasello, Michael 2002. Gondolkodás és kultúra. Osiris Kiadó, Budapest.

TOMASEllo, MichaEL ed. 2003. The new psychology of language. Cognitive and functional approaches to language structure. Lawrence Erlbaum, Mahwah-London. 
Traugott, Elizabeth Closs 1989. On the rise of epistemic meanings in English: an example of subjectification in semantic change. Language 65: 31-55. http://doi.[-] org/10.2307/414841

Traugott, Elizabeth Closs - Dasher, Richard B. 2002. Regularity in Semantic Change. Cambridge University Press, Cambridge.

VERSEGHY FERENC 1821. Magyar Grammatika. A' Királyi Magyar Universitás' Betüivel, Budánn.

\section{The metamorphosis of pasts}

\section{Modifications in the semantic and narrative grounding of the Hungarian past tenses after the 18th century}

A significant change occurred in the tense system of Hungarian during the 18th and 19th centuries: earlier speakers used four different past tenses while, by the middle of the 19th century, only one past tense remained for construing a scene as taking place prior to the time of discourse. This seemingly simple historical process, however, proves to be a highly complex transformation in the conceptualization of temporality in every respect: the object of modification was the temporal reference frame of clauses and discourses as such. The theoretical framework of the investigation presented here is Langacker's Cognitive Grammar. The paper discusses two formerly used past tenses: (1) the simple past tense that expressed events completed prior to the processing time, and (2) the imperfective past that expressed past events as ongoing actions or events directly experienced or evoked by the conceptualizer. The imperfective past focused on epistemic immediacy while the simple past expressed non-immediacy, construed in the clausal context. By contrast, the modern way of conceptualizing the past involves deictic past tense; i.e., it is temporal distance that has the basic function, with the aspectual content of the verbs being responsible for everything else. nessing.

Keywords: epistemic grounding, immediacy, imperfective past, simple past, temporality, wit-

TOLCSVAI NAGY GÁBOR

Eötvös Loránd Tudományegyetem

Konstantin Filozófus Egyetem, Nyitra 